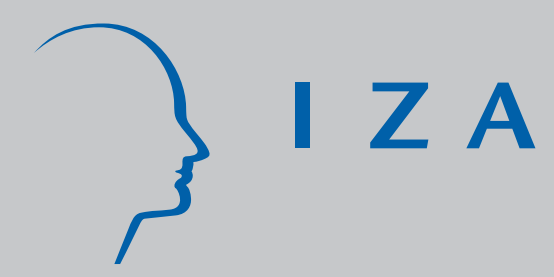

IZA DP No. 2345

Immigrant Selection Systems

and Immigrant Health

Barry R. Chiswick

Yew Liang Lee

Paul W. Miller

September 2006 


\title{
Immigrant Selection Systems and Immigrant Health
}

\author{
Barry R. Chiswick \\ University of Illinois at Chicago \\ and IZA Bonn \\ Yew Liang Lee \\ University of Western Australia \\ Paul W. Miller \\ University of Western Australia \\ and IZA Bonn
}

\section{Discussion Paper No. 2345 \\ September 2006}

\author{
IZA \\ P.O. Box 7240 \\ 53072 Bonn \\ Germany \\ Phone: +49-228-3894-0 \\ Fax: +49-228-3894-180 \\ E-mail: iza@iza.org
}

\begin{abstract}
Any opinions expressed here are those of the author(s) and not those of the institute. Research disseminated by IZA may include views on policy, but the institute itself takes no institutional policy positions.

The Institute for the Study of Labor (IZA) in Bonn is a local and virtual international research center and a place of communication between science, politics and business. IZA is an independent nonprofit company supported by Deutsche Post World Net. The center is associated with the University of Bonn and offers a stimulating research environment through its research networks, research support, and visitors and doctoral programs. IZA engages in (i) original and internationally competitive research in all fields of labor economics, (ii) development of policy concepts, and (iii) dissemination of research results and concepts to the interested public.
\end{abstract}

IZA Discussion Papers often represent preliminary work and are circulated to encourage discussion. Citation of such a paper should account for its provisional character. A revised version may be available directly from the author. 
IZA Discussion Paper No. 2345

September 2006

\section{ABSTRACT}

\section{Immigrant Selection Systems and Immigrant Health}

This paper is an analysis of the determinants of self-reported health status of immigrants, with a particular focus on type of visa used to gain admission. The concept of "health capital" and an immigrant selection and adjustment model are employed. The empirical analysis uses the three waves of the Longitudinal Survey of Immigrants to Australia (panel I). Immigrant health is greater for immigrants who are younger, more educated, male, more proficient in English, and living outside of an immigrant ethnic enclave. Immigrant health is poorest for refugees and best for independent (economic) migrants, and declines with duration in the destination. There is, therefore, evidence for favorable selectivity on the basis of health status among family and especially independent migrants, as well as a tendency toward "regression to the mean" with duration in the destination.

JEL Classification: $\quad$ I12, J15, J61, F22

Keywords: immigrants, health status, visa, longitudinal data

Corresponding author:

Barry R. Chiswick

Department of Economics

University of Illinois at Chicago

601 South Morgan Street

Chicago, IL 60607-7121

USA

E-mail: brchis@uic.edu

\footnotetext{
Comments received on an earlier draft from Evelyn Lehrer and the Health Economics Research Seminar, University of Illinois at Chicago and the Center for Demography and the Economics of Aging, Graduate School of Business, University of Chicago, are appreciated. Chiswick acknowledges the research support provided by the Institute of Government and Public Affairs, University of Illinois. Miller acknowledges financial support from the Australian Research Council.
} 
September 2006

\section{IMMIGRANT SELECTION SYSTEMS AND IMMIGRANT HEALTH}

\section{INTRODUCTION}

Countries with a history of large immigration movements have typically required some type of formal health screening as part of the immigration process. ${ }^{1}$ In the United States, the Immigration Act of 1882 banned entry of persons likely to become a public charge, including those not able to work due to disability, while the Immigration Act of 1891 excluded persons suffering from certain contagious diseases. Similarly, Australia and Canada have general requirements concerning the level of health of their immigrants.

The health screening of immigrants is intended to ensure that risks to public health in the host community are minimized, that public expenditure on health and community services is contained, and that native-born residents will not be crowded out from suitable access to health and other community services. As a result, as noted in VandenHeuvel and Wooden (1999, p.94) regarding Australia, immigration is usually viewed as “....a selective process whereby those who do not meet certain health requirements are not granted visas to migrate”.

Immigrants are, however, sometimes reported to suffer poorer general health than the host population. Poor health may be the consequence of a number of factors associated with the migration experience. These include economic hardship, separation from family, friends and social networks, changes in lifestyle such as diet, work, recreation and religious practices, lack of knowledge about the health care system of the host country, poor knowledge of their rights, difficulties in communicating with health practitioners arising from linguistic and cultural barriers, and discrimination stemming from xenophobia and racism (Powles and Gifford (1990), Bourdillon and Bennegadi (1992)).

These factors might be expected to impact more intensely on some immigrants than on others. In particular, immigrants who are selected for entry into a country on the basis of their likely economic success (such as in the skilled worker programs in

\footnotetext{
${ }^{1}$ For relevant discussions see, for example, McCance (1992) and Kraut (1994) for the United States, King (1992) for Australia, and Bollini (1992) and Keane and Gushulak (2001) for inter-country comparisons.
} 
the U.S., Australia and Canada) might have health outcomes that differ systematically from those of family reunification or humanitarian (refugee) immigrants. While studies of the health status of immigrants in the US and Canada (e.g., Hernandez and Charney (1998), Schultz (1984) Kasper (2002) and Perez (2002)) have reported many interesting findings concerning immigrant health and how this changes with duration of residence in the destination, there is a lack of evidence on the links between motive for migration and health status. This paper redresses this gap in the literature.

Specifically, the paper examines the determinants of immigrant's post-arrival health in a major immigrant receiving country, Australia. The analysis focuses on the importance of the degree of selectivity of specific groups of immigrants for entry into Australia, with immigrants selected for entry on the basis of their likely economic success (determined using a skill based points system) being distinguished from family reunification and humanitarian (refugee) immigrants. The comparison between the points-tested and other immigrants has the potential to offer insights into the consequence for immigrant health of adoption of a skill points-based immigrant selection regime, as has been suggested for the US by Chiswick (1981, 1983), and later by others.

The structure of the paper is as follows. The theory and hypotheses relating to immigrant health are outlined in Section II. Section III provides a discussion of the special features of the Longitudinal Survey of Immigrants to Australia, the data set studied in the empirical analysis. Descriptive analyses are contained in Section IV. Multiple regression analyses of the determinants of health status are presented in Section V. Section VI presents a summary and conclusion.

\section{THE MODEL AND HYPOTHESES ${ }^{2}$}

Immigrants' health status can be modelled in terms of the stock of immigrant health at arrival and post-migration investments in health.

\section{a. Pre-Immigration Considerations}

Immigrants tend to be different from others in their origin who do not migrate. They tend to be young adults, better educated, forward looking, and entrepreneurial, among other characteristics associated with favorable self-selectivity for labor market

\footnotetext{
${ }^{2}$ This analysis is in the spirit of Grossman (1972a)(1972b).
} 
success. These characteristics associated with favorable labor market outcomes in the destination would also be associated with favorable selectivity of migrants on the basis of their health. In the data under study, the health status at immigration is not known, but variables to explain this health status may be developed.

Age at immigration is surely relevant as health status tends to decline with age. Gender is also relevant as women tend to report a poorer health status than do men, presumably for gender-related biological reasons (Pol and Thomas (1992, pp.298-299)). So too would be the general health status of the country of origin, as measured, for example, by the life expectancy or infant mortality rate in the origin.

To the extent that the more educated have greater knowledge and better decision-making skills, they can be expected to generate a higher level of health in the origin, and hence arrive with a higher health status (Pol and Thomas (1992, pp. 311312), Grossman (1972a)(1972b)). Moreover, those with more education would have a higher value of time and hence more to lose from being ill, as well as greater wealth to finance investments in health care.

Health status may also be linked to the type of immigrant visa obtained. Employers may be more reluctant to sponsor an ill immigrant than would, for example, a close family member. A sickly individual may be more reluctant to leave the origin to make his or her way in an unfamiliar labor market as an independent (economic) migrant than, say, a refugee who can expect public assistance (including medical care) for a longer period of time in the destination. Entry health criteria may also be looser for refugees and family migrants than for economic migrants.

\section{b. Post-Immigration Considerations}

Several factors that enter into the demand for health care influence reported changes in health status with duration in the destination. The hypotheses developed above for why those with higher levels of schooling would make greater investments in health capital prior to immigration also apply to their investments in health status in the destination. That is, those with higher levels of schooling would have a higher health status because of greater knowledge, better decision-making skills, a higher opportunity cost of time lost due to illness, and greater wealth to finance investments in health, even when health status at arrival is held constant.

It has been found that those who are currently married have a higher health status (Pol and Thomas (1992, pp.306-308), Waite and Gallagher (2000), pp.47-77)). 
This may arise for several reasons. One is that marriage is endogenous with respect to health status. Those who are ill are less likely to marry, stay married and to remarry if a first marriage ends. Moreover, those who are married are more likely to have a "live-in" health support system if nursing care or personal care is needed, and information from their spouse regarding health status and healthier living. Related to this, the presence of children may be linked to the health status of adult immigrants. Some health problems (e.g., colds and flu) may be transmitted from children to their parents, as children may provide an additional source of contact with the host population.

Access to health care may also be influenced by enclave, concentration, or neighborhood effects. Living in an enclave area with a larger number of immigrants from the same origin provides information and support networks that may be relevant not only for the labor market, but also for the market for health care (Julian and Easthope (1996, p.106), Halpern (1993, p.599), Cochrane and Bal (1988, p.363), Anderson (1987, p.423), Muhlin (1979, p.264), Kraus (1969, p.92)). Alternatively, the insularity of the enclave may result in less access to the best available health care.

Furthermore, knowledge of the language of the destination may be relevant for health status. Greater proficiency in the destination language would facilitate communication with health care providers, both in and out of hospitals, as well as facilitate understanding written instructions, including information regarding medications (Julian and Easthope (1996, p.106), Karmi (1991, p.9), Lin and Pearse (1990, p.220), Powles and Gifford (1990, p.77), Reid and Trompf (1990, p.xiv)).

An important general factor in the analysis of the health status of immigrants is their duration in the destination. Holding age at immigration constant, a longer duration of residence implies an older age, and hence, other things being the same, poorer health status. Other variables, however, are not necessarily the same. For example, suppose self-reported health status is assessed, at least in part, relative to those in the surrounding environment. A migrant from a low-income, poor-health status country to a high-income healthy country may reassess his objectively unchanged health status downward as the norm has changed (Shaw et al. (1999, pp.225-226), Toole and Waldman (1997, p.12), Sundquist (1995, p.133)). Moreover, reported health status may decline with duration due to a “regression to the mean”. If, due to favorable self-selectivity in migration and immigrant related health restrictions, only those who are very healthy at the time of migration actually move, yet, with the 
passage of time their health status will tend to gravitate toward the mean. Moreover, a change in climate and diet may lower health status but these adverse effects may be revealed only with the passage of time in the destination.

On the other hand, the immigrant's health may improve in the destination with access to $21^{\text {st }}$ century health and medical care if this is not available in the origin and the higher real incomes that are available in the destination. Immigrant health status may also appear to improve with duration in cross-sectional data if the least healthy die or remigrate (Palloni and Arias, 2004). ${ }^{3}$

Finally it may be that migrants are healthy prior to migration, but migration is bad for one's health. Migration is a stressful experience, as is unemployment, divorce or the death of a close relative (Pol and Thomas (1992, pp. 238-243)). People have health capital investments that may be specific to their origin. These include family and friends as physical and emotional support systems and familiar lifestyles. People optimize their health for where they live. If they move to a new environment, support systems may not be there, and because relative prices differ, a different mix of inputs for maintaining health capital may be optimal. If they do not adjust to the new environment, their health status would decrease with duration.

\section{c. Hypotheses}

While separate supply and demand equations for health capital (status) cannot be identified, because of the absence of data on the price of health capital (status) and identifying instruments, the reduced form health equation can be estimated. This reduced form can be used to test the following hypotheses:

Self-reported health status would be higher for those who have more education, are male, are married, migrate at a younger age, are independent (economic) or business related migrants rather than family related, with refugees in the poorest health, are more proficient in the destination language, and come from high-income/healthier countries. Several factors suggest that immigrant health would decline with a longer duration, including ageing, a regression to the mean, living in an unfamiliar environment and a reduced family support system. Particularly for

\footnotetext{
${ }^{3}$ A study for Israel found that immigrants who died between the 1983 and 1995 Censuses had significantly lower earnings in 1983 than those who survived to 1995, other variables being the same (Beenstock, Chiswick and Paltiel, 2005). The lower earnings in 1983 may have been due to a poorer health status.
} 
immigrants from low-income, low-health status countries, subjective self-reported health status may decline as destination norms replace origin norms, or objectively they may rise as they have access to modern health care systems and as their income (and ability to finance health care) increases.

\section{THE LONGITUDINAL SURVEY OF IMMIGRANTS TO AUSTRALIA}

The empirical section of this paper is based on the Longitudinal Survey of Immigrants to Australia (LSIA), a longitudinal study of recently arrived immigrants who received their visas before entry into Australia. The population represented in the sample is all Principal Applicants, aged 15 years and over, who arrived in Australia with their visas in the two-year period of September 1993 to August 1995. ${ }^{4}$ Immigrants were interviewed three times: at approximately five or six months after arrival; at 18 months after arrival; and at 42 months (3 1/2 years) after arrival.

Principal Applicant immigrants selected for interview were those who settled in State and Territory capital cities (including major urban centers close to capital cities such as Newcastle and Wollongong), as well as Cairns. Only 4 to 5 percent of the total of Principal Applicant immigrants are excluded from the coverage of the survey because they lived outside of these areas.

The final LSIA sample was 5,192 Principal Applicant arrivals. This represents about seven percent of the total Principal Applicants that arrived in the two-year survey period. The population from which the sample was selected at random was stratified according to visa eligibility category and also by about fifty regions or countries of birth. ${ }^{5}$

Five broad visa groups are identified in this analysis: (i) Humanitarian; (ii) Preferential Family; (iii) Concessional Family; (iv) Business Skills and Employer

\footnotetext{
${ }^{4}$ The Principal Applicant is the person who qualified for the visa that enabled the person and the person's spouse and minor children to immigrate. Excluded from the scope of the survey are New Zealand citizens for whom there is unrestricted mobility to Australia and those granted a visa while resident in Australia.

${ }^{5}$ A feature of the sampling frame for the LSIA is that Principal Applicants in smaller States and Territories were over-sampled. Weights are available to adjust for this. These estimation weights were modified to account for sample attrition between the first and third waves of the survey. All analyses in this study use relevant estimation weights. Experiments show that the use of these weights has only a modest effect on the statistical results.
} 
Nomination; and (v) Independent. These are listed in the likely order of favorable selectivity from the least to the most highly selected.

Immigrants who enter Australia under the Humanitarian program are primarily refugees and asylees and will share many of the characteristics of humanitarian immigrants in other countries. The humanitarian visa program in Australia is similar to the refugee visa program in the U.S.

The Preferential Family category provides for the entry of spouses, fiancés, unmarried dependent children, children for adoption or adopted by Australians while overseas, parents meeting a "balance of family" test, as well as aged dependent, "last remaining," “special need” and orphan child relatives. Except for siblings of U.S. citizens, this category corresponds, broadly speaking, to the family reunification immigrants in the US.

The Concessional Family category allows for the sponsorship of nondependent children, parents who do not meet the "balance of family" test, siblings, and nieces and nephews. A points test is applied to this category based mainly on the skills and age of the applicant, and aspects of the family relationship. Although it includes siblings, this category combines equities acquired as a distant relative and acquired through possessing labor market skills. There are no parallels to this category in the U.S. or in the recent discussions of a points system for rationing some visas.

The Business Skills category aims to attract people with successful careers in business and who have a genuine and realistic commitment to establishing new businesses or actively participating in existing businesses that will benefit Australia. The Employer Nomination Scheme is designed to enable Australian employers who are unable to fill vacancies within the Australian labor market or through their own training efforts to recruit skilled workers from overseas. Most major immigrant receiving countries have similar schemes for attracting special skills. These two programs are comparable to the investor and employment visa categories in U.S. immigration law.

The Independent category emphasises the selection of young adults who are skilled and employable. It does this through a points test based on skill (schooling, educational qualifications, job-training, and occupation), age, and English language proficiency. There is currently no comparable category in U.S. immigration law.

The information collected in the LSIA by way of personal interview includes demographic characteristics, socioeconomic status, family background and location 
details. Data on the Principal Applicant's demographic characteristics include gender, age, marital status, country of birth, ethnicity, and health. Education level, employment status (before and after migration), occupation, and income from all sources form the major socioeconomic status variables. The information on the type of visa to gain entry is from administrative records. Duration in Australia is known from the wave of the survey, and all persons in a given wave have the same duration.

Immigrants in the LSIA were asked to rate their health status over the previous four weeks. ${ }^{6}$ The five response options given in the questionnaire were: very good, good, fair, poor, and very poor (see Appendix A).

The approach taken in the econometric analysis focuses on the impact of the visa at entry on immigrant health. First, a model is estimated that includes only visa category variables. This specification will show the gross effect on health status of both the measured (e.g., age, formal skill) and unmeasured (e.g., motivation for migration) factors related to visa category. Then, demographic and other personal characteristics, including country of birth, are added to the analysis. The motivation for incorporating the personal characteristics into the specification based only on visa category follows Miller (1999) in that it will enable an assessment of whether the health requirements imposed on immigrants for entry into Australia are useful screens for physical health outcomes. ${ }^{7}$

6 Immigrants were also asked to report any long-term health conditions (i.e., conditions that have lasted, or are likely to last, 6 months) that restricted them in any physical activities or from doing work. Few immigrants reported long-term medical conditions (around 5 percent at arrival), and these seldom change in the postmigration period. Among the few changes over the 3 years of the LSIA from wave 1 to wave 3, some were suspect (e.g., individuals reporting a lost limb in an early interview but not a subsequent one). Those who reported a long term health problem at arrival were deleted from the analysis, although purging this small group does not affect the conclusions drawn from the analysis. Those who reported long-term health problems were disproportionately refugees.

${ }^{7}$ The health requirement applies, in principle, to all immigrants. People with active tuberculosis cannot get a visa. All other medical conditions are assessed individually. For example, while HIV/AIDS testing is compulsory for all immigrants aged 15 or older, an applicant diagnosed as positive for HIV/AIDS is not automatically refused. Rather, an assessment is made of the estimated cost and resource impact on the Australian community. The health requirement can be waived for Humanitarian and Preferential Family visa entrants. See Fact Sheet 22 (The Health Requirement), http://www.immi.gov.au/facts/22health.htm 
In a third model, the country or region of birth fixed effects variables are replaced by variables reflecting characteristics of the origin. Although birthplace dichotomous variables are useful in accounting for variations in the data, they generally lack behavioral interpretation. The life expectancy, birthplace concentration and distance measures used in their place have behavioral interpretations, and so this model is more likely to enhance understanding of the reasons for the variations in health across groups of immigrants. A final model considered includes the birthplace dichotomous (fixed effects) variables, as well as birthplace behavioral variables (distance from the origin, life expectancy in the origin, and the birthplace concentration measure in Australia).

\section{DESCRIPTIVE STATISTICS}

Table 1 presents information on self-assessments of health in the month prior to each of the three interviews. The first column of this table refers to the wave 1 data. At about six months after arrival (wave 1), 54 percent of the respondents rated their health as being very good, 39 percent rated it as good, and less than 8 percent rated their health as fair or poor (including very poor). The results from study of the second and third waves of data (columns (iii) and (iv)) suggest that there is a deterioration in health status, such that at the third wave of interviews, which is only three years later, only 41 percent of the immigrants rated their health as very good and a further 45 percent as good. At this time, 15 percent of the immigrants indicated that their health status was less than good.

There is no obvious explanation for the deterioration in health status. The sequence of questions in the survey is the same in each of the three waves. One possibility is that there is selective remigration, such that those who subsequently leave Australia are relatively healthier. To provide a cursory examination of this possibility, the wave 1 self-reported health status of those who were known from administrative records to have left Australia by the time of the second wave of interviews was examined. As presented in column (ii) of Table 1, 58 percent of those who had left Australia by the time of the second interview rated their health as very good and 30 percent rated it as good. These figures are broadly in line with the data for wave 1 presented in column (i) of the same table, and in any case the small 
numbers involved (74 immigrants representing a weighted sample size of 1,045) cannot have a major impact on the aggregate-level figures.

Another possible explanation for the decline in health status is the ageing of the population from wave one to wave three. Yet, a comparison of the population reporting each health status aged 15 to 61 years in wave one with those aged 18 to 64 years in wave one, which mimics the ageing process between waves one and three, indicates only a trivial change due to ageing. ${ }^{8}$

Other candidates for explanations of this decline in health status include regression to the mean by visa category, and the reporting of health status on the basis of relative rather than absolute terms. If the explanation is based on the selective migration argument, different patterns might be expected for categories of immigrants characterized by greater selectivity in migration (e.g., Independent immigrants) than for those immigrants characterized by a lower degree of selectivity (e.g., the Humanitarian category). Similarly, if the explanation is based on the nature of the comparisons (relative to a changing norm or absolute health status) one would expect the changes over time to differ for immigrants from developed countries (e.g., UK, US, Germany), where the health standards are similar to those in Australia, than for immigrants from less-developed countries (e.g., India, Africa).

Table 2 provides wave 1 information on self-assessed health by visa category. The Humanitarian entrants, followed by the Preferential Family immigrants, were most likely of all immigrant groups to have rated their health as fair, poor or very poor, but only 11 percent and 9 percent did so, respectively. Only 4 to 5 percent reported low levels of health in the other visa categories. These results are likely to arise because, as discussed above, some health requirements are waived for Humanitarian and Preferential Family visa entrants when they are selected to migrate to Australia. Moreover, these migrants are least likely to base their decision to

\begin{tabular}{lcc}
\hline${ }^{8}$ Percent reporting health status in wave one by age: & \\
\cline { 2 - 3 } Health Status & $15-61$ & Age (Years) \\
\hline Very Good & 53.7 & $18-64$ \\
Good & 38.6 & 53.5 \\
Fair & 6.6 & 38.7 \\
Poor & 1.1 & 6.6 \\
Very Poor & 0.1 & 1.1 \\
\hline Total & 100.0 & 0.1 \\
\hline
\end{tabular}


migrate to Australia on purely economic considerations. Furthermore, the refugee experience itself may have resulted in a determination of their health.

Information on self-assessed health over the previous 4 weeks by visa category at the time of the third interview is presented in Table 3. These data show that there is deterioration in health status for each of the visa category groups. According to Julian and Easthope (1996), the longer migrants stay in Australia, the less healthy they become. ${ }^{9}$ They reason that it is not simply a function of age but of a changed lifestyle. The diet of most Southern Europeans and Asians is higher in vegetables and lower in animal fats than the standard Australian diet. ${ }^{10}$ As immigrants adopt the Australian diet, they tend to develop “Australian” diseases, such as heart failure. The decline in general health appears to be slightly more intense for Concessional Family immigrants, and to a lesser extent Independent immigrants, and less intense for Humanitarian immigrants. In other words, the decline in general health is less for the groups of immigrants that are the least selected for migration, and it is greater among immigrant groups that are relatively more highly selected. This suggests there is some merit to the "selection in migration and regression to the mean" argument. It will be examined further in the statistical analyses presented in the next section.

A preliminary assessment can be made as to whether the deterioration in general health standards has its explanation in the nature of the comparisons being undertaken. First, an indicator of health standards across countries is established. There are a number of candidates, including the life expectancy at birth, the percentage of the population with access to health services, the infant mortality rate, and health expenditures as a percentage of GDP. The life expectancy in the country of birth is used as a general indicator as it is available for the diverse range of countries represented in the LSIA data. ${ }^{11}$ Second, countries are categorized broadly

\footnotetext{
${ }^{9}$ For similar findings in the US, Canada and Sweden, see Hernandez and Charney (1998), Kaspar (2002), Perez (2002), and Bengtsson and Kirk (2002).

${ }^{10}$ Young (1986) finds that the life expectancy of Southern European immigrants is higher than that of the Australian-born population, and that Southern Europeans are less susceptible to serious disorders associated with diet.

11 These data were obtained for most countries from United Nations (1994). The data refer to 1992. For countries not included in this data source the relevant information was obtained from the CIA World Factbook 2001 (http://www.odci.gov/cia/publications/factbook/). While these data refer to 2001, this
} 
as "good" and "poor” health using a threshold of a life expectancy at birth of 70.4. ${ }^{12}$ Then cross-tabulations of the data on self-reported health status by the health status of the origin are reported in Table 4.

The Table 4 data show that self-assessments of health at the time of the first interview are more favorable for immigrants from "good” health countries than for those from "poor” health countries. Hence, 58 percent of immigrants from countries where the life expectancy at birth is 70.4 or more rated their health as "very good," compared to only 48 percent of immigrants from countries where the life expectancy at birth is less than 70.4. In other words, immigrants from countries with relatively low health standards report low levels of health in Australia.

It is also apparent from this table that the general level of health deteriorated between wave 1 and wave 3 for both groups of immigrants. Moreover, the extent of the decline in self-reported health status is similar for the two groups. ${ }^{13}$ This suggests that the decline in the general level of health observed for the total population is not a reflection of changes in "Norms" from those that prevailed in the country of origin to one consistent with the general level of health in Australia.

\section{REGRESSION RESULTS}

\section{a. Wave 1 Analysis}

Table 5 presents estimates from models where the dependent variable is the self-assessed health in the month prior to the first interview (5-6 months after arrival). As noted above, information on health was coded in five categories, namely (a) very poor, (b) poor, (c) fair, (d) good, and (e) very good. For the models presented in the first three columns, a dichotomous variable has been formed from this information. Individuals reporting either good or very good health are categorized as in "Good

difference in timing of the two data sources should not constitute a problem given the small changes in life expectancies over short time periods.

12 This figure represents the median life expectancy for the sample of immigrants in the LSIA. As this median is found using unweighted data, the two subsamples need not be of the same size when sample weights are applied.

${ }^{13}$ Relating the change between wave one and wave three in the percentage of each birthplace group reporting they were in very good health to the life expectancy reveals a negative, but statistically insignificant, association. 
Health” and assigned a value of one, while immigrants reporting either fair, poor or very poor health are categorized as in "Poor Health" and assigned a value of zero. Results from linear probability analysis are presented here: results from a probit model are similar, with the OLS being presented for ease of the interpretation of the marginal effects. The final column (Table 5, column iv), takes advantage of all five health categories by using ordered probit analysis. While the table contains results for several model specifications and methods of estimation, in each case a positive coefficient indicates better health.

The results from a simple linear probability model (i.e. OLS estimation) that includes only the visa categories are contained in Table 5 column (i). In this model, the coefficients of the visa variables indicate that self-assessment of health among immigrants who are not points tested, namely those with Humanitarian and Preferential Family visas, is relatively poor. At first glance this suggests that an indirect benefit of selecting immigrants (via a points test) on the basis of potential economic success is better health outcomes in the immediate post-arrival period.

The estimates presented in Table 5 column (ii) are from a linear probability model that augments the simple model considered above with information on age at migration, gender, education, English language proficiency, marital status, presence of children and birthplace. The findings show that, relative to immigrants with Independent visas, Humanitarian immigrants report a lower current health status, whereas Concessional Family immigrants report a higher level of health, but both coefficients are at the margin of significance. It is apparent though that control for the personal characteristics reduces the effect associated with Humanitarian class immigrants by about 60 percent (compare Table 5, columns (i) and (ii)). Note, however, that this is not due to "over-controlling” by the inclusion of the South East Asia birthplace variable. When the birthplace dichotomous variables are deleted and replaced by behavioral variables describing the birthplace (compare Table 5, columns ii and iii), the coefficient and t-ratio on the humanitarian variable hardly change.

The basis for the marginally significant better health of Concessional Family immigrants compared to Independent immigrants is unclear. Recall that this visa category combines points testing and family characteristics, and those who enter Australia with this visa are expected to be less intensely selected than Independent 
immigrants who enter on the basis of points testing alone. ${ }^{14}$ It suggests there is merit to combining family relationships and potential for economic success, at least if the objective is health outcomes. As will be shown later, however, any apparent health advantage for the Concessional Family visa category is short-lived.

Many of the standardizing variables included in the model are statistically significant. The personal characteristics associated with good self-assessed health are migration at a younger age, being male and being proficient in English. These effects are consistent with the hypotheses outlined in Section II. Females have a probability of self-assessed good health that is 5 percentage points lower than that of males. The family structure variables, however, do not appear to have any significant effects on self-assessment of health status. ${ }^{15}$

Immigrants who were proficient in English are about 6 percentage points more likely to self-assess their general health as good than are immigrants with limited English skills. One interpretation of the positive coefficient on the English skills variable is that good English skills reduce the feeling of alienation that can lead to poor self-assessment of health outcomes. Another is that good English skills result in more adequate medical and health care. This finding complements other results reported in the literature showing that immigrants with good destination language skills have higher earnings and lower rates of unemployment than immigrants who lack proficiency in the dominant language (see, for example, Chiswick and Miller (1995)). Immigrants who are not able to communicate in the destination language appear disadvantaged on both economic and health dimensions.

Seven of the birthplace coefficients in Table 5 show a statistically significant (at the 10 percent level or higher) lower self-reported health status than those from Southern Europe. These are immigrants from Western Europe, Northern Europe, the

\footnotetext{
${ }^{14}$ This finding differs from the links between visa status and employability reported by Miller (1999). Miller (1999) shows that unemployment rate differentials across migration categories appear to reflect the underlying characteristics of the immigrants, rather than immigrant category per se. Other studies that have reported similar findings for labor market outcomes are Wooden (1990), Chiswick and Miller (1992) and Duleep and Regets (1996).

15 These findings are consistent with a study of sickness benefits (sick leave) among immigrants in Sweden during the 1980s. Bengtsson and Scott (2002) find that among immigrants sick days increased with duration in the country, were greater for refugees than for labor migrants, greater for females and declined with a higher level of education. The effects of marital status and children were ambiguous.
} 
USSR and the Baltic States, South East Asia, North East Asia, Southern Asia and the remaining countries. There is, however, no other pattern of note in these results.

The additional explanatory variables included in Table 5 column (iii) are for birthplace concentration, life expectancy at birth, and geographic distance between the country of origin and Australia, but without the birthplace dichotomous variables. These changes to the specification do not lead to much difference in the results for the other variables in the column (ii) specification of the same table.

Residence in a region with a relatively high concentration of persons from the same birthplace is associated with poorer self-assessments of health. Other studies have shown that those who live in immigrant concentration areas have poorer English skills and lower earnings (see Chiswick and Miller (1995)(2005)). Living within the ethnic community may retard access to modern medical care, as it seems to limit abilities to acquire proficiency in English. Alternatively, it may reflect the greater propensity of healthier immigrants to leave the ethnic concentration area.

There is a positive coefficient for the variable for life expectancy at birth in the country of origin on "good health" in the destination, although the association is not statistically significant. ${ }^{16}$ The positive coefficient on the geographic distance variable suggests that immigrants from countries more distant from Australia, and hence more likely to be subject to greater selectivity in migration, report higher levels of general health.

The final column of Table 5 presents results from an attempt to utilize more fully the information in the self-assessment of health status. The five categories of self-assessed health noted above are ordered, and membership in each of these health categories can be analyzed using an ordered probit model. With this model the conditional probability that individual i with characteristics $X_{i}$ will self-assess his/her health as being of the $j^{\text {th }}$ level may be written as:

$$
\operatorname{Pr}\left(\operatorname{GoodH}_{i}=J \mid X_{i}\right)=\Phi\left(\mu_{J}-\beta X_{i}\right)-\Phi\left(\mu_{J-1}-\beta X_{i}\right), \quad J=1, \ldots, 5
$$

where $\Phi$ is the cumulative density function of the standard normal distribution, and GoodH $_{i}=1$ if the individual self-assesses his/her health as very poor, and $G o o d H_{i}=2$

16 Replacing the linear life expectancy at birth variable by a quadratic or by dichotomous variables for the $<65,65-69,70-74$ and $75+$ life expectancy at birth categories yields findings that were neither consistent across methods of estimation (probit, ordered probit) for a particular set of data, nor consistent for the analyses based on the data for the first and third interviews. Accordingly, the simple linear specification is retained in these analyses. 
if the individual self-assesses his/her health as poor. This coding continues with the final coding being GoodH $_{i}=5$ if the individual self-rates his/her health as very good.

The specification in Table 5 column (iv) is the same as that of the linear probability model in column (iii). The estimated threshold parameters ( $\hat{\mu}$ 's) are all highly significant, thus indicating that the self-assessed health categories used in the analysis are distinct. Educational attainment, being proficient in English, as well as the Concessional Family and Business Skills/Employer Nomination Scheme visa categories are associated with better self-rated health, while being female, humanitarian immigrants, and an older age at migration are associated with poorer self-rated health. The family structure variables do not affect self-assessed health status. Residence in areas of relatively high concentration of persons born in the same country as the respondent is associated with lower self-reported health status, whereas greater geographic distance between an immigrant's country of origin and Australia leads to better self-assessed health. About 58 percent of cases are predicted correctly with this model.

In the ordered probit model, a positive coefficient can only be unambiguously associated with changes in predicted membership of the very poor or very good (selfassessed) health categories. Given this, it is instructive to predict probability distributions for a number of variables to show how changes in the personal characteristics impact across the full set of self-rated health categories. Predicted distributions across the health categories by educational attainment, gender and English skills are reported in Table 6.

These results show that the better educated have a higher probability of reporting being in very good general health, and lower probabilities of being in each of the four lesser health categories. The comparison of immigrants with 18 and eight years of education shows that the extra 10 years of education are associated with a five percentage point increase in the probability of being in very good health, and with a 3.5 percentage point reduction of being only in good health (Table 6). Males are 12 percentage points more likely than females to report being in very good general health. Proportionately, more females report being in good or fair general health.

Knowledge of English, other variables being the same, is associated with a higher probability of the immigrant reporting being in very good health (by 14 
percentage points), and with lower probabilities of being in each of the four lesser health categories.

\section{b. Wave 3 Analysis}

Estimates from models where the dependent variable is self-assessed health over the month prior to the wave 3 interview are presented in Table 7. Column (i) lists the OLS results from a simple model that relates self-assessed health only to migration category. Immigrants who were issued Humanitarian and Preferential Family visas are less likely to self-assess their health as good compared with those who were granted Independent visas. This is the same finding as in the wave 1 interview (column (i) of Table 5). The estimated mean differential in self-reported health status between Independent and Preferential Family immigrants and that between Independent and Humanitarian class immigrants are similar in the wave 1 (Table 5) and wave 3 (Table 7) results.

The second column of Table 7 contains OLS results of the regression model that includes variables for age at migration, education, gender, English language proficiency, marital status, presence of children and birthplace. The set of results indicates that, compared with immigrants who were granted Independent visas, Humanitarian visa recipients are less likely to self-rate their health as good or very good. The partial effect on the Humanitarian variable is consistent with the mean differentials reported in column (i), but greater than that reported for the wave 1 data.

The wave 3 results (Table 7) indicate no significant difference in reported health status between the Independent migrants and the Business-skilled/Employer Nomination Scheme immigrants. This latter group is heavily dominated by arrivals under the Employer Nomination Scheme (similar to the employment based visas in U.S. immigration law).

The probability of immigrants rating their health as good is influenced by whether they migrated at a younger age, are male, or were proficient in English at the wave 3 interview. The direction of these partial effects is the same as was reported from wave 1.

Compared to immigrants from Southern Europe, the birthplace coefficients that are negative and significant at the 10 percent level are those for the "Englishspeaking developed countries”, Western Europe, the USSR and the Baltic States, South East Asia, North East Asia, and Southern Asia. The comparison of these 
birthplace results to those obtained from the same model using the wave 1 sample (Table 5 column (ii)) shows that, in wave 3, the coefficients of the Northern Europe and Remaining countries variables are no longer statistically significant, whereas the coefficient of the "English-speaking developed countries" variable remains negative but becomes statistically significant. The variability in the birthplace coefficients suggests that modeling of the influences captured by these variables may be useful.

The specification in Table 7 column (iii) replaces the birthplace variables by the variables for birthplace concentration, life expectancy at birth and geographic distance. These changes are associated with little change in the substantial negative coefficient on the Humanitarian visa variable. They are, however, associated with a reduction in the impact on self-assessed health of the Business Skills/Employer Nomination Scheme visa category variable.

The probability of reporting good health associated with arriving in Australia at a younger age, being male, or being proficient in English at the time of the wave 3 interview is not affected in any material way by the inclusion of the three behavioral variables reflecting country of origin. In comparison, the assessments of health associated with educational attainment are affected by the augmentation of the estimating equation. In the model reported in Table 7, column (ii), the education variable has no impact on the probability of reporting good health. However, in the column (iii) results the better educated are shown to be less likely to report their health as good. A similar change in the specification did not lead to a change in significance of the education variable in the analysis of the wave 1 data. This suggests that the interaction between educational attainment and the other behavioral variables has changed. For example, the better educated are more likely than their less well-educated counterparts to acquire English language skills. Omitting the English language proficiency variable results in an insignificant education effect. The better educated are also less likely to live in immigrant concentration areas. Omitting the birthplace concentration variables leads to the coefficient on the education variable becoming insignificant.

Immigrants who reside in regions with a relatively high concentration of individuals from their country of origin are also less likely to report their health as good than those who live outside the areas of high ethnic concentrations. Moreover, this effect has strengthened with duration of residence in Australia, as might be 
expected where the passage of time enables appropriate comparisons to be made with others in Australia from the same origin.

The results also show that those from countries with a relatively high life expectancy at birth are marginally more likely to report their general health as being good. This latter finding is particularly important. The average health status does not vary with health status in the country of origin just after immigration (wave one at 5 to 6 months after migration), but with time those from countries with a lower health status are more likely to reassess their health status downward. This may be due to a shifting of the reference point for their health status from their origin country norm to the Australian norm.

Finally, the distance variable is statistically insignificant in Table 7. This compares with the analysis of the wave one data where the linear distance term was positive and significant. This variable is argued to capture the degree of selectivity in immigration. These results suggest that the factors captured by the variable have some impact in the expected direction shortly after arrival, but no impact $3 \frac{1}{2}$ years after arrival. One might expect that the favorable selectivity on the basis of health at immigration would deteriorate to the mean with duration in Australia.

Column (iv) of Table 7 presents results from an ordered probit model that has the same specification as the linear probability model in column (iii). These results are broadly similar to those reported in column (iii), and so will not be discussed in detail.

\section{c. Changes over Time}

The analyses conducted for the two waves of data presented above could be linked in several ways. The method employed needs to take into account the fact that the panel is quite short (three years), and for most of the sample there is little change over time in the reported health status and the explanatory variables. ${ }^{17}$

\footnotetext{
${ }^{17}$ A fixed effects probit model can be applied to a specification of the estimating equation with interaction terms for wave of data collection for the subset of individuals whose health status changes over the period under review (see the Chiswick and Miller (2006) study of English proficiency). All observations can be included in OLS estimation of this panel model. However, the changes in coefficients across waves of data collection are slight, suggesting there may be minimal advantage to this approach. An alternative might be to use a random effects model, though prior research using these data and a number of dependent variables has indicated that this approach does not lead to material changes in findings (see, for example, Cobb-Clark (2006)).
} 
Some information on the role of the unobserved influences on health outcomes can be gained through the estimation of a bivariate probit model. In this model the two equations are those for health status in waves 1 and 3 . The advantage of adopting this method of estimation can be seen by considering an immigrant reporting a favorable health status at the wave 1 interview. This immigrant might be similarly placed at the wave 3 interview. In each equation there will be a large positive prediction error in the single equation model of contemporary health status. The bivariate probit model offers a more efficient method of estimation than the consistent single equation probit equations estimated above as it takes into account the correlation between the disturbances. The general form for the bivariate probit model is

$$
\operatorname{Pr}\left(\text { GoodH }_{i}^{\text {Wave1 }}=1, \text { Good }_{i}^{\text {Wave3 }}=1\right)=F\left(\beta^{\text {Wave1 }} X_{i}^{\text {Wave } 1}, \beta^{\text {Wave } 3} X_{i}^{\text {Wave } 3}, \rho\right)
$$

where the $\beta$ and $X$ vectors are described above, and $\rho$ is the correlation coefficient between the residuals in the estimating equations for waves one and three.

Estimates of this model, for the sample with valid data in both waves one and three, are presented in Table 8. The first two columns of results are for singleequation probit models. Table 8, Column (i) corresponds to the OLS model reported in Table 5, column (ii), though in this instance the estimation has been carried out using the sub-sample of individuals who were also in the sample in wave three, with weights adjusted for this attrition. Table 8, Column (ii) corresponds to the OLS model reported in Table 7, column (ii). ${ }^{18}$ The salient features of these results are the same as those reported previously (Tables 5, 7) and hence they will not be discussed further.

The final two columns of Table 8 list the results of the bivariate probit model, with the first list of results being for wave one and the second for wave three. These results show a statistically significant, moderately sized positive estimate of 0.39 for rho $(\rho)$, the correlation coefficient between the errors in the estimating equations for waves one and three. In other words, unobserved factors that result in an immigrant being relatively more likely to report good (poor) general health in wave one persist such that they are also relatively more likely to report good (poor) health in wave three which is taken three years later. These factors could be related to unmeasured personal characteristics (e.g., weight, height, size), personal behavior (e.g., exercises,

\footnotetext{
${ }^{18}$ The small change in sample size is due to missing values on wave 1 information for several cases where there are valid data in wave three.
} 
eats healthy foods, smokes or drinks alcohol), childhood experiences, genetic factors, or other unmeasured determinants of health.

Taking account of the correlation between the disturbance terms in the analyses for waves one and three has little impact on the estimated coefficients - the only pattern that is perceptible is that the estimates for the bivariate probit model tend to be slightly smaller, in absolute value, than the single-equation probit estimates. In other words, the effects of the unobservables that can be captured through this method of estimation do not greatly affect the estimated impacts in the independent probit models. This mirrors findings from analysis of immigrants' employment status and English skills using these data that have attempted to take unobservables into account (e.g., Cobb-Clark (2006), Chiswick and Miller (2006)).

The impact of taking account of the links between the unobservables in the two sets of analyses can be made clearer through the computation of predictions of being in good health in waves one and three from the two types of probit models (independent and bivariate). These are presented in Table 9.

The probability of being in good health is quite high in each wave of the LSIA. At the mean value of all variables it is 94 percent in wave one and 87 percent in wave three. If these probabilities were independent of each other, the probability of being in good health in both waves one and three is 82 percent, that is, when calculated as the product of the probabilities from the two single-equation probit models. However, as the correlation coefficient between the disturbance terms in the two models is significant and sizeable, failure to take it into account will result in predictions that are inferior to those obtained from the bivariate probit model. However, when account is taken of this correlation, at the mean value of all variables, the joint probability of being in good health in both waves one and three is 83 percent, only slightly higher than that calculated without recognition of the correlation between the disturbance terms in the two health models.

Examination of the final two columns in Table 8 shows that the predicted likelihoods of being in good health in both waves one and three are higher for each characteristic when computed from the bivariate probit model that takes account of the correlation between the error terms than when calculated from the independent probit models. The gap between the two sets of predictions is only one percentage point at the means, and it opens up to only three percentage points for those who are not proficient in English. While for some groups with low probabilities of being in 
good health the difference in predictions is even greater, there are few individuals in the sample with the combinations of characteristics associated with these low probabilities. Thus, while these results show that the unobservables that are captured through the correlation coefficient in the bivariate probit model matter in the study of immigrant health, taking them into account has only a minor impact on the coefficients obtained from study of each wave of data independently.

\section{SUMMARY AND CONCLUSIONS}

This paper has been concerned with the analysis of the health of immigrants. It focuses on the relationship between visa category and immigrants' health status, and how this relationship changes with duration in the destination. The paper also examines the role that economic and demographic factors play in determining immigrants' health status.

Based on the concept of "health capital" and the immigrant adjustment model, testable hypotheses are developed. It is, for example, hypothesized that self-reported health status is better, the younger the age, the higher the level of schooling, among males, among those who are married, among those coming from "healthier" countries of origin, among those who migrated a longer distance, and among those who immigrated under employment related visas compared with family-based visas, with refugees (humanitarian visas) having the lowest health status.

Analysis of data from the Longitudinal Survey of Immigrants to Australia shows that immigrants' self-reported health status varies with visa category, being better among those selected on the basis of their potential for economic success. The reported health of all visa groups, however, deteriorates with duration of residence in Australia. The patterns regarding visa category became weaker when the other socioeconomic determinants of health status (e.g., age, educational attainment, English proficiency) are held constant. Indeed, other than for the poor health of those who entered Australian on humanitarian visas, there are minimal differences in selfreported health across visa types, particularly after several years of residence in Australia, when human capital variables that influence visa category are held constant. This is consistent with evidence on the links between visa category and labor market outcomes reported in other studies for Australia (e.g., Miller (1999) and the US (Duleep and Regets (1996)), and with the links between visa category and English language skills (e.g., Chiswick and Miller (2006)). In other words, visa category per 
se, except for refugees, does not apparently matter for the economic and social outcomes of immigrants when the human capital characteristics that influence visa category are held constant.

The other hypotheses developed in this study are generally supported by the data. Higher reported health status is generally associated with a younger age, higher levels of education, being male, and being proficient in English. Living among many others from one’s origin/ethnic group is associated with lower health status.

There is a moderate correlation between the unexplained (error term) component of health status in wave one and wave three. This statistically significant correlation of 0.4 suggests a moderate persistence over time in the effects of unmeasured variables, including pre-immigration experiences, genetic factors and unmeasured behavioral factors that result in some individuals being healthier than others. Taking account of this correlation has little impact on the estimates obtained for the probit model, or on the predictions of health status. This is consistent with findings from other studies of these data that have shown there is little apparent advantage from applying fixed effects or random effects estimators to these longitudinal data. This may be associated with the limited time (three years) over which the respondents were followed.

Self-reported health status decreases (from 54 percent to 41 percent "very good") with the three-year increase in duration in Australia from 6 months to $3 \frac{1}{2}$ years. This is apparently not due to the aging of the population or to the selective return migration of healthier individuals. To some extent it reflects a "regression to the mean.” If new immigrants are favorably selected for good health, with the passage of time their health will decline toward the mean. To some extent it reflects a change in the reference point-the decline is somewhat greater among those from lower life expectancy countries, possibly due to a change in the norm from the origin to the destination, although the effect of this variable is not statistically significant in wave 1. It might also be that the decline represents an initial adjustment to a new climate, diet, life-style, and the general immigrant experience found in Australia. A longer longitudinal survey would be needed to determine whether this decline with duration continues, stabilizes itself, or is reversed with a longer stay in the destination.

In brief, the paper demonstrates that models of health capital and immigrant adjustment can be profitably employed in the study of the health of immigrants. It 
also demonstrates that the factors that determine visa status, both those that are measured and unmeasured, are associated with immigrant health. Visa status (other than the humanitarian visa), however, does not add to the predictive power of the model of health status when other measured variables are held constant. This finding is consistent with research into the links between immigrant selection and employment outcomes (Duleep and Regets (1996), Miller (1999) and language skills (Chiswick and Miller (2006)). The lower levels of success of family migrants and, in part, for humanitarian (refugee) migrants compared to independent (employment related) migrants is largely due to their poorer measured human capital characteristics. 


\section{REFERENCES}

Anderson, Joan M. (1987). "Migration and Health: Perspectives on Immigrant Women”, Sociology of Health and Illness, Vol. 9, No. 4, pp. 410-438.

Beenstock, Michael, Barry R. Chiswick and Ari Paltiel, (2005) "Endogenous Assimilation and Immigration Adjustment in Longitudinal Data," IZA Institute for the Study of Labor, Working Paper No. 1840, Bonn

Bengtsson, Tommy and Kirk Scott (2002). "Immigrant Consumption of Sickness Benefits in Sweden, 1981-1991”, Lund Papers in Economic History, No. 83, 2002, Lund University, Lund, Sweden

Bollini, Paola (1992). "Health Policies for Immigrant Populations in the 1990s. A Comparative Study in Seven Receiving Countries”, International Migration, Vol. 30 (Special Issue: Migration and Health in the 1990s), pp. 103-119.

Bourdillon, F. and R. Bennegadi (1992). "Migration and Health - What Does the Future Hold?”, International Migration, Vol. 30 (Special Issue: Migration and Health in the 1990s), pp. 199-205.

Central Intelligence Agency (2001). The World Factbook 2001, http://www.odci.gov/cia/publications/factbook/.

Chiswick, Barry R. (1981). “Guidelines for the Reform of Immigration Policy”, William Fellner, ed., Essays in Contemporary Economic Problems: Demand Productivity and Population, 1981/82, American Enterprise Institute, pp. 309-347.

Chiswick, Barry R. (1983). “An Alternative Approach to Immigration Policy: Rationing By Skill”, Population Research and Development Review, Vol. 2, February, pp. 21-33.

Chiswick, Barry R. and Paul W. Miller (1992). Post-Immigration Qualifications in Australia: Determinants and Consequences, Australian Government Publishing Service, Canberra.

Chiswick, Barry R. and Paul W. Miller (1995). “The Endogeneity between Language and Earnings: International Analyses”, Journal of Labor Economics, Vol. 13, No. 2, pp. 246-288.

Chiswick, Barry R. and Paul W. Miller (2005) "Do Enclaves Matter in Immigrant Adjustment?” City and Community, Vol. 4, No. 1, March, pp. 5-36.

Chiswick, Barry R. and Paul W. Miller (2006). "Language Skills and Immigrant Adjustment: The Role of Immigration Policy,” in Deborah Cobb-Clark and Siew-Ean Khoo (eds.) Public Policy and Immigrant Settlement, Edward Elgar, Cheltenham, UK, IZA Discussion Paper No. 1419. 
Cobb-Clark, Deborah (2006). "Selection Policy and the Labour Market Outcomes of New Immigrants," in Deborah Cobb-Clark and Siew-Ean Khoo (eds.) Public Policy and Immigrant Settlement, Edward Elgar, Cheltenham, UK,

Cochrane, R. and S. S. Bal (1988). "Ethnic Density Is Unrelated to Incidence of Schizophrenia”, British Journal of Psychiatry, Vol. 153, pp. 363-366.

Department of Immigration and Multicultural Affairs (2001), Fact Sheet 22: The Health Requirement, http://www.immi.gov.au/facts/22health.htm.

Duleep, Harriet Orcutt and Mark C. Regets (1996). "Admission Criteria and Immigrant Earnings Profiles”, International Migration Review, Vol. 30, No. 2, pp. 571-590.

Grossman, Michael (1972a). "On the Concept of Health Capital and the Demand for Health”, Journal of Political Economy, Vol. 80, pp. 223-255.

Grossman, Michael (1972b). The Demand for Health: A Theoretical and Empirical Investigation, New York: NBER Occasional Papers No. 119.

Halpern, David (1993). “Minorities and Mental Health”, Social Science and Medicine, Vol. 36, No. 5, pp. 597-607.

Hernandez, Donald J. and Evan Charney (1998). From Generation to Generation: The Health and Well-Being of Children in Immigrant Families, National Academy Press, Washington, DC.

Julian, Roberta and Gary Easthope (1996). “Migrant Health” in C. Grbich, ed., Health in Australia, Prentice Hall, Sydney, pp. 103-125.

Karmi, Ghada (1991). "The Health Status and Health Beliefs of Two London Migrant Communities”, International Migration, Vol. 29, pp. 5-12.

Kaspar, Violet (2002). "Mental Health of Immigrant and Non-Immigrant Children and Youth", Paper presented at the Conference on Canadian Immigration Policy for the $21^{\text {st }}$ Century, October 2002, Queen's University, Kingston, Ontario, Canada.

Keane, V. P. and Brian D. Gushulak (2001). "The Medical Assessment of Migrants: Current Limitations and Future Potential”, International Migration, Vol. 39, No. 2, pp. 29-41.

King, K. (1992). "Medical Screening of Migrants in Australia”, International Migration, Vol. 30 (Special Issue: Migration and Health in the 1990s), pp. 233-237.

Kraus, J. (1969). “The Relationship of Psychiatric Diagnoses, Hospital Admission Rates, and Size and Age Structure of Immigrant Groups”, Medical Journal of Australia, Vol. 2, pp. 91-95. 
Kraut, Alan M. (1994). Silent Travellers: Germs, Genes, and the "Immigrant Menace”, Basic Books, New York.

Lin, Vivian and Warwick Pearse (1990). “A Workforce at Risk”, in Janice Reid and Peggy Trompf, eds., The Health of Immigrant Australia, Harcourt Brace Jonanovich, Sydney, pp. 206-249.

McCance, C. (1992). "Medical Screening of Migrants: Current National Requirements in the United States”, International Migration, Vol. 30 (Special Issue: Migration and Health in the 1990s), pp. 215-219.

Miller, Paul W. (1999). "Immigration Policy and Immigrant Quality: The Australian Points System”, American Economic Review, Papers and Proceedings, Vol. 89, No. 2, pp. 192-197.

Muhlin, Gregory L. (1979). "Mental Hospitalization of the Foreign-Born and the Role of Cultural Isolation”, International Journal of Social Psychiatry, Vol. 25, pp. 258-266.

Perez, Claudio E. (2002). "Health Status and Health Behaviour Among Immigrants”, Supplement to Health Reports, Vol. 13, Statistics Canada Catalogue, 82-003, Ottawa, Canada.

Pol, Louis G. and Richard K. Thomas (1992). The Demography of Health and Health Care, Plenum Press, New York.

Palloni, Alberto and Elizabeth Arias (2004) "Paradox Lost: Explaining the Hispanic Adult Mortality Advantage,” Demography, 41(3), August, pp 385-415.

Powles, John and Sandra Gifford (1990). "How Healthy Are Australia’s Immigrants?” in Janice Reid and Peggy Trompf, eds., The Health of Immigrant Australia, Harcourt Brace Jonanovich, Sydney, pp. 77-107.

Reid, Janice and Peggy Trompf (1990). The Health of Immigrant Australia, Harcourt Brace Jonanovich, Sydney.

Schultz, T. Paul (1984). "The Schooling and Health Children of US Immigrants and Natives”, Research in Population Economics, Vol. 5, pp. 251-288.

Shaw, Mary, Danny Dorling and George Davey Smith (1999). "Poverty, Social Exclusion, and Minorities” in Michael Marmot and Richard G. Wilkinson, eds., Social Determinants of Health, Oxford University Press, New York.

Sundquist, Jan (1995). "Living Conditions and Health: A Population-Based Study of Labour Migrants and Latin American Refugees in Sweden and Those Who Were Repatriated", Scandinavian Journal of Primary Health Care, Vol. 13, No. 2, pp. 128-134. 
Toole, Michael J. and Ronald J. Waldman (1997). “The Public Health Aspects of Complex Emergencies and Refugee Situations”, Annual Review of Public Health, Vol. 18, pp. 283-312.

United Nations (1994). Human Development Report 1994, Oxford University Press, New York.

VandenHeuvel, Adriana and Mark Wooden (1999). New Settlers Have Their Say How Immigrants Fare Over the Early Years of Settlement, Department of Immigration and Multicultural Affairs, Canberra.

Veall, Michael R. and Klaus F. Zimmermann (1996). "Pseudo- $R^{2}$ Measures for Some Common Limited Dependent Variable Models”, Journal of Economic Surveys, Vol. 10, No. 3, pp. 241-259.

Waite, Linda and Maggie Gallagher (2000). The Case for Marriage: Why Married People are Happier, Healthier and Better Off Financially, Doubleday, New York.

Wooden, Mark (1990). Migrant Labour Market Status, Australian Government Publishing Service, Canberra.

Young, Christabel M. (1986). Selection \& Survival: Immigrant Mortality in Australia, Australian Government Publishing Service, Canberra. 
TABLE 1: Distributions of Self-Assessed Health Over 4 Weeks Prior to Interviews of Immigrants 15-64 Years of Age at Immigration, Longitudinal Survey of Immigrants to Australia (Percent)

\begin{tabular}{|c|c|c|c|c|c|}
\hline & $\begin{array}{c}\text { (i) } \\
\text { Wave } 1\end{array}$ & 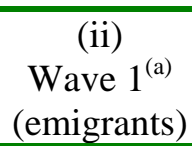 & 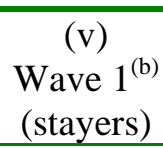 & $\begin{array}{c}\text { (iii) } \\
\text { Wave } 2\end{array}$ & $\begin{array}{c}\text { (iv) } \\
\text { Wave } 3\end{array}$ \\
\hline Very Good & 53.6 & 57.7 & 54.1 & 44.7 & 40.6 \\
\hline Good & 38.7 & 29.7 & 38.9 & 43.2 & 44.6 \\
\hline Fair & 6.6 & 8.8 & 6.0 & 9.7 & 11.1 \\
\hline Poor & 1.1 & 2.0 & 0.9 & 2.3 & 3.2 \\
\hline Very Poor & 0.1 & 1.9 & 0.1 & 0.1 & 0.6 \\
\hline Total $^{(\mathrm{b})}$ & 100.0 & 100.0 & 100.0 & 100.0 & 100.0 \\
\hline Sample size & 4,789 & 74 & 3,348 & 4,126 & 3,349 \\
\hline Population size & 67,767 & 1,045 & 46,771 & 63,368 & 57,981 \\
\hline
\end{tabular}

${ }^{(a)}$ Persons in wave one who were known to have emigrated from Australia by wave two.

${ }^{(b)}$ Persons in wave three for whom their health status were known in wave one.

${ }^{(c)}$ Totals may not sum to zero due to rounding.

All data are weighted using sample weights to reflect the population size.

Source: Longitudinal Survey of Immigrants to Australia (Waves One, Two and Three). 
TABLE 2: Self-Assessed Health Over 4 Weeks Prior to Interviews by Visa Category of Immigrants 15-64 Years of Age at Immigration, Longitudinal Survey of Immigrants to Australia, Wave One

\begin{tabular}{|c|c|c|c|c|c|c|}
\hline \multirow[b]{2}{*}{$\begin{array}{l}\text { Health } \\
\text { Status }\end{array}$} & \multicolumn{5}{|c|}{ Visa Category (Percent) } & \multirow[b]{2}{*}{$\begin{array}{c}\% \text { of } \\
\text { Population }^{(\mathrm{c})}\end{array}$} \\
\hline & Independent & $\begin{array}{c}\text { Business } \\
\text { Skills/ENS }^{(a)}\end{array}$ & $\begin{array}{c}\text { Concessional } \\
\text { Family }\end{array}$ & $\begin{array}{c}\text { Preferential } \\
\text { Family }\end{array}$ & Humanitarian & \\
\hline Very good & 61.56 & 67.00 & 62.94 & 51.21 & 42.39 & 53.56 \\
\hline Good & 34.09 & 28.12 & 33.09 & 39.99 & 46.22 & 38.69 \\
\hline Fair & 3.49 & 4.42 & 3.37 & 7.39 & 10.21 & 6.58 \\
\hline Poor & 0.71 & 0.46 & 0.60 & 1.30 & 0.92 & 1.05 \\
\hline Very poor & 0.16 & 0.00 & 0.00 & 0.11 & 0.26 & 0.12 \\
\hline Total $^{(\mathrm{b}),(\mathrm{c})}$ & 100.00 & 100.00 & 100.00 & 100.00 & 100.00 & 100.00 \\
\hline $\begin{array}{l}\% \text { of } \\
\text { Population }\end{array}$ & 18.64 & 3.72 & 8.38 & 56.22 & 13.05 & 100.00 \\
\hline
\end{tabular}

${ }^{(a)}$ ENS denotes Employer Nomination Scheme.

(b) The total number of unweighted cases is 4,789. All data are weighted using sample weights to reflect a population of 67,767 .

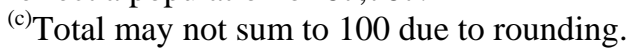

Source: Longitudinal Survey of Immigrants to Australia (Wave One). 
TABLE 3: Self-Assessed Health Over 4 Weeks Prior to Interviews by Visa Category of Immigrants 15-64 Years of Age at Immigration, Longitudinal Survey of Immigrants to Australia, Wave Three

\begin{tabular}{|c|c|c|c|c|c|c|}
\hline \multirow[b]{2}{*}{$\begin{array}{l}\text { Health } \\
\text { Status }\end{array}$} & \multicolumn{5}{|c|}{ Visa Category (Percent) } & \multirow[b]{2}{*}{$\begin{array}{c}\% \text { of } \\
\text { Population }^{(\mathrm{c})}\end{array}$} \\
\hline & Independent & $\begin{array}{c}\text { Business }^{(a)} \\
\text { Skills/ENS }^{(a)}\end{array}$ & $\begin{array}{l}\text { Concessional } \\
\text { Family }\end{array}$ & $\begin{array}{l}\text { Preferential } \\
\text { Family }\end{array}$ & Humanitarian & \\
\hline Very good & 44.74 & 52.31 & 41.86 & 39.74 & 35.16 & 40.58 \\
\hline Good & 45.41 & 41.09 & 47.39 & 44.44 & 43.02 & 44.55 \\
\hline Fair & 9.06 & 5.75 & 9.54 & 11.47 & 14.23 & 11.08 \\
\hline Poor & 0.51 & 0.48 & 0.79 & 3.77 & 6.40 & 3.20 \\
\hline Very poor & 0.28 & 0.36 & 0.43 & 0.58 & 1.19 & 0.59 \\
\hline Total $^{(\mathrm{b}),(\mathrm{c})}$ & 100.00 & 100.00 & 100.00 & 100.00 & 100.00 & 100.00 \\
\hline $\begin{array}{l}\% \text { of } \\
\text { Population }\end{array}$ & 17.95 & 3.30 & 8.28 & 56.31 & 14.15 & 100.00 \\
\hline
\end{tabular}

${ }^{(a)}$ ENS denotes Employer Nomination Scheme.

(b) The total number of unweighted cases is 3,349. All data are weighted using sample weights to reflect a population of 57,981.

(c) Total may not sum to 100 due to rounding.

Source: Longitudinal Survey of Immigrants to Australia (Wave Three). 
TABLE 4: Self-Assessed Health Over 4 Weeks Prior to Interviews by Life Expectancy of Immigrants 15-64 Years of Age at Immigration, Longitudinal Survey of Immigrants to Australia, Waves One and Three

\begin{tabular}{lccc|ccc}
\hline & \multicolumn{5}{c|}{ Wave 1 } \\
\cline { 2 - 6 } $\begin{array}{l}\text { Health } \\
\text { Status }\end{array}$ & Poor & Good & $\begin{array}{c}\text { \% of } \\
\text { population }^{(\mathrm{b})}\end{array}$ & Poor & Good & $\begin{array}{c}\text { \% of } \\
\text { population }^{(\mathrm{c})}\end{array}$ \\
\cline { 2 - 7 } Very good & 48.41 & 57.79 & 53.56 & 35.98 & 44.71 & 40.58 \\
Good & 41.07 & 36.73 & 38.69 & 46.54 & 42.76 & 44.55 \\
Fair & 8.80 & 4.76 & 6.58 & 12.72 & 9.60 & 11.08 \\
Poor & 1.56 & 0.63 & 1.05 & 4.20 & 2.30 & 3.20 \\
Very poor & 0.17 & 0.08 & 0.12 & 0.56 & 0.63 & 0.59 \\
$\begin{array}{l}\text { Total } \\
\text { (b), (c) }\end{array}$ & 100.00 & 100.00 & 100.00 & 100.00 & 100.00 & 100.00 \\
$\begin{array}{l}\text { \% of } \\
\text { population }\end{array}$ & 45.12 & 54.88 & 100.00 & 47.29 & 52.71 & 100.00 \\
\hline
\end{tabular}

(a) Countries are categorized broadly as "good" and "poor" health using a threshold life expectancy of 70.4 years, which is the median life expectancy in the unweighted data. The different sample sizes for the "Poor" and "Good" health countries arises from the application of the sample weights.

${ }^{(b)}$ The total number of unweighted cases in waves 1 and 3 are 4,789 and 3,349, respectively. The respective data are weighted using sample weights to reflect a population of 67,767 and 57,981.

${ }^{(\mathrm{c})}$ Total may not sum to 100 due to rounding.

Source: Longitudinal Survey of Immigrants to Australia (Waves One and Three). 
TABLE 5: Self-Assessed Good Health Over 4 Weeks Prior to Interviews of Immigrants 15-64 Years of Age at Immigration, Longitudinal Survey of Immigrants to Australia, Wave One

\begin{tabular}{|c|c|c|c|c|}
\hline & & OLS & & $\begin{array}{c}\text { Ordered } \\
\text { Probit }\end{array}$ \\
\hline Variable & (i) & (ii) & (iii) & (iv) \\
\hline Constant & $\begin{array}{c}0.956 \\
(140.17)\end{array}$ & $\begin{array}{l}0.976 \\
(37.38)\end{array}$ & $\begin{array}{c}0.835 \\
(14.74)\end{array}$ & $\begin{array}{l}2.537 \\
(9.99)\end{array}$ \\
\hline $\begin{array}{l}\text { Visa Category (Indepenc } \\
\text { Humanitarian }\end{array}$ & $\begin{array}{l}-0.070 \\
(4.88)\end{array}$ & $\begin{array}{l}-0.028 \\
(1.71)\end{array}$ & $\begin{array}{l}-0.030 \\
(1.69)\end{array}$ & $\begin{array}{l}-0.149 \\
(1.91)\end{array}$ \\
\hline Preferential Family & $\begin{array}{l}-0.044 \\
(5.09)\end{array}$ & $\begin{array}{l}-0.003 \\
(0.18)\end{array}$ & $\begin{array}{l}0.005 \\
(0.31)\end{array}$ & $\begin{array}{l}-0.032 \\
(0.41)\end{array}$ \\
\hline Concessional Family & $\begin{array}{l}0.004 \\
(0.32)\end{array}$ & $\begin{array}{l}0.024 \\
(1.91)\end{array}$ & $\begin{array}{l}0.025 \\
(1.84)\end{array}$ & $\begin{array}{l}0.194 \\
(2.40)\end{array}$ \\
\hline Business Skills/ENS ${ }^{(b)}$ & $\begin{array}{l}-0.006 \\
(0.32)\end{array}$ & $\begin{array}{l}0.015 \\
(0.78)\end{array}$ & $\begin{array}{l}0.007 \\
(0.32)\end{array}$ & $\begin{array}{l}0.219 \\
(1.90)\end{array}$ \\
\hline Education & (a) & $\begin{array}{l}0.002 \\
(1.28)\end{array}$ & $\begin{array}{l}0.001 \\
(0.68)\end{array}$ & $\begin{array}{l}0.013 \\
(1.98)\end{array}$ \\
\hline Age at migration & (a) & $\begin{array}{l}-0.001 \\
(2.00)\end{array}$ & $\begin{array}{l}-0.001 \\
(2.47)\end{array}$ & $\begin{array}{l}-0.004 \\
(2.01)\end{array}$ \\
\hline Female & (a) & $\begin{array}{l}-0.052 \\
(6.46)\end{array}$ & $\begin{array}{l}-0.061 \\
(6.80)\end{array}$ & $\begin{array}{l}-0.311 \\
(7.50)\end{array}$ \\
\hline Proficient in English & (a) & $\begin{array}{l}0.057 \\
(5.53)\end{array}$ & $\begin{array}{l}0.053 \\
(4.89)\end{array}$ & $\begin{array}{l}0.350 \\
(7.42)\end{array}$ \\
\hline $\begin{array}{l}\text { Family Structure } \\
\text { MUS }^{(\mathrm{g})}\end{array}$ & (a) & $\begin{array}{l}-0.010 \\
(0.72)\end{array}$ & $\begin{array}{l}-0.004 \\
(0.29)\end{array}$ & $\begin{array}{l}-0.013 \\
(0.20)\end{array}$ \\
\hline $\mathrm{OS}^{(\mathrm{h})}$ & (a) & $\begin{array}{l}0.002 \\
(0.16)\end{array}$ & $\begin{array}{l}-0.006 \\
(0.40)\end{array}$ & $\begin{array}{l}0.060 \\
(0.92)\end{array}$ \\
\hline KIDS $^{(i)}$ & (a) & $\begin{array}{l}-0.006 \\
(0.57)\end{array}$ & $\begin{array}{l}-0.006 \\
(0.52)\end{array}$ & $\begin{array}{l}-0.063 \\
(1.34)\end{array}$ \\
\hline $\begin{array}{l}\text { Birthplace (Southern Eu } \\
\text { English-speaking } \\
\text { developed countries }\end{array}$ & (a) & $\begin{array}{l}-0.012 \\
(0.52)\end{array}$ & (a) & (a) \\
\hline Western Europe & (a) & $\begin{array}{l}-0.053 \\
(2.53)\end{array}$ & (a) & (a) \\
\hline Northern Europe & (a) & $\begin{array}{l}-0.073 \\
(1.80)\end{array}$ & (a) & (a) \\
\hline
\end{tabular}




\begin{tabular}{|c|c|c|c|c|}
\hline Eastern Europe & (a) & $\begin{array}{l}-0.002 \\
(0.09)\end{array}$ & (a) & (a) \\
\hline $\begin{array}{l}\text { The USSR and the Baltic } \\
\text { States }\end{array}$ & (a) & $\begin{array}{l}-0.139 \\
(3.86)\end{array}$ & (a) & (a) \\
\hline The Middle East & (a) & $\begin{array}{l}-0.019 \\
(1.25)\end{array}$ & (a) & (a) \\
\hline North Africa & (a) & $\begin{array}{l}-0.036 \\
(1.20)\end{array}$ & (a) & (a) \\
\hline South East Asia & (a) & $\begin{array}{l}-0.102 \\
(7.06)\end{array}$ & (a) & (a) \\
\hline North East Asia & (a) & $\begin{array}{l}-0.057 \\
(3.71)\end{array}$ & (a) & (a) \\
\hline Southern Asia & (a) & $\begin{array}{l}-0.035 \\
(2.42)\end{array}$ & (a) & (a) \\
\hline $\begin{array}{l}\text { South and Central } \\
\text { America }\end{array}$ & (a) & $\begin{array}{l}-0.016 \\
(0.61)\end{array}$ & (a) & (a) \\
\hline Remaining countries & (a) & $\begin{array}{l}-0.051 \\
(2.07)\end{array}$ & (a) & (a) \\
\hline Birthplace concentration & (a) & (a) & $\begin{array}{l}-0.004 \\
(3.70)\end{array}$ & $\begin{array}{l}-0.009 \\
(2.47)\end{array}$ \\
\hline ife expectancy at birth & (a) & (a) & $\begin{array}{l}0.001 \\
(1.49)\end{array}$ & $\begin{array}{l}0.005 \\
(1.25)\end{array}$ \\
\hline Distance/1000 & (a) & (a) & $\begin{array}{l}0.004 \\
(3.21)\end{array}$ & $\begin{array}{l}0.022 \\
(3.84)\end{array}$ \\
\hline$\hat{\mu}_{1}$ & (c) & (c) & (c) & $\begin{array}{c}0.820 \\
(15.09)\end{array}$ \\
\hline$\hat{\mu}_{2}$ & (c) & (c) & (c) & $\begin{array}{c}1.702 \\
(55.75)\end{array}$ \\
\hline$\hat{\mu}_{3}$ & (c) & (c) & (c) & $\begin{array}{c}3.113 \\
(97.68)\end{array}$ \\
\hline$R^{2}$ & 0.008 & 0.049 & 0.046 & $0.001^{(\mathrm{d})}$ \\
\hline$=/ \chi^{2}$ & $10.09^{(\mathrm{e})}$ & $10.70^{(\mathrm{e})}$ & $13.34^{(\mathrm{e})}$ & 46.05 \\
\hline Prediction success rate (\%) & (c) & (c) & (c) & 58.49 \\
\hline Sample size & 4789 & 4789 & $3915^{(\mathrm{f})}$ & $3915^{(\mathrm{f})}$ \\
\hline
\end{tabular}

Note: 't' statistics in parentheses.

${ }^{(a)}$ Variable not entered. 
(b) ENS denotes Employer Nomination Scheme.

(c) Not relevant.

(d) The Pseudo $R^{2}$ is calculated as $1-\left(\mathrm{L}_{\mathrm{m}} / \mathrm{L}_{0}\right)$, where $\mathrm{L}_{\mathrm{m}}=$ the log-likelihood value of the model and $\mathrm{L}_{0}$ $=$ the log-likelihood value if the non-intercept coefficients are restricted to zero (see Veall and Zimmermann, 1996).

${ }^{(\mathrm{e})}$ Figures listed for the OLS models are F statistics.

${ }^{(f)}$ Sample size reduces by 874 due to rejection of immigrants with zero birthplace concentration (874), and missing value for the life expectancy at birth measure (2). For two cases, both were missing.

${ }^{(\mathrm{g})}$ Whether a spouse who was part of the migrating unit is present in the household.

${ }^{\text {(h) }}$ Whether a spouse who was not part of the migrating unit is present in the household.

${ }^{(i)}$ Whether children in the household.

Source: Longitudinal Survey of Immigrants to Australia (Wave One). 
TABLE 6: Predicted Distribution Across Self-Assessed Health Categories by Personal Characteristics of Immigrants 15-64 Years of Age at Immigration, Longitudinal Survey of Immigrants to Australia

\begin{tabular}{|c|c|c|c|c|c|c|}
\hline & & & S Stat & & & \\
\hline & Very good & Good & Fair & Poor & Very poor & Total \\
\hline Educational Attainment & & & & & & \\
\hline 8 & 50.0 & 42.1 & 6.8 & 1.0 & 0.1 & 100.0 \\
\hline 10 & 51.0 & 41.4 & 6.5 & 0.9 & 0.1 & 100.0 \\
\hline 12 & 52.1 & 40.8 & 6.2 & 0.9 & 0.1 & 100.0 \\
\hline 14 & 53.1 & 40.0 & 5.9 & 0.8 & 0.1 & 100.0 \\
\hline 16 & 54.2 & 39.3 & 5.7 & 0.8 & 0.1 & 100.0 \\
\hline 18 & 55.2 & 38.6 & 5.4 & 0.7 & 0.1 & 100.0 \\
\hline Gender & & & & & & \\
\hline Male & 58.9 & 36.0 & 4.5 & 0.6 & 0.0 & 100.0 \\
\hline Female & 46.6 & 44.2 & 7.9 & 1.2 & 0.1 & 100.0 \\
\hline English Skills at Migrat & & & & & & \\
\hline Knew English & 58.3 & 36.4 & 4.6 & 0.6 & 0.0 & 100.0 \\
\hline Did not know English & 44.4 & 45.4 & 8.6 & 1.4 & 0.2 & 100.0 \\
\hline
\end{tabular}

Source: Authors' calculations based on Table 8 (Wave One). 
TABLE 7: Self-Assessed Good Health Over 4 Weeks Prior to Interviews of Immigrants 15-64 Years of Age at Immigration, Longitudinal Survey of Immigrants to Australia, Wave Three

\begin{tabular}{|c|c|c|c|c|}
\hline & & OLS & & $\begin{array}{c}\text { Ordered } \\
\text { Probit }\end{array}$ \\
\hline Variable & (i) & (ii) & (iii) & (iv) \\
\hline Constant & $\begin{array}{c}0.902 \\
(74.29)\end{array}$ & $\begin{array}{c}0.942 \\
(18.21)\end{array}$ & $\begin{array}{l}0.829 \\
(8.29)\end{array}$ & $\begin{array}{l}2.171 \\
(7.29)\end{array}$ \\
\hline $\begin{array}{l}\text { Visa Category (Independ } \\
\text { Humanitarian }\end{array}$ & $\begin{array}{l}-0.120 \\
(5.32)\end{array}$ & $\begin{array}{l}-0.079 \\
(3.00)\end{array}$ & $\begin{array}{l}-0.084 \\
(3.12)\end{array}$ & $\begin{array}{l}-0.169 \\
(1.99)\end{array}$ \\
\hline Preferential Family & $\begin{array}{l}-0.060 \\
(4.05)\end{array}$ & $\begin{array}{l}-0.006 \\
(0.28)\end{array}$ & $\begin{array}{l}-0.011 \\
(0.48)\end{array}$ & $\begin{array}{l}-0.061 \\
(0.81)\end{array}$ \\
\hline Concessional Family & $\begin{array}{l}-0.009 \\
(0.41)\end{array}$ & $\begin{array}{l}0.012 \\
(0.52)\end{array}$ & $\begin{array}{l}0.018 \\
(0.72)\end{array}$ & $\begin{array}{l}0.071 \\
(0.78)\end{array}$ \\
\hline Business Skills/ENS ${ }^{(b)}$ & $\begin{array}{l}0.032 \\
(1.20)\end{array}$ & $\begin{array}{l}0.055 \\
(1.97)\end{array}$ & $\begin{array}{l}0.045 \\
(1.42)\end{array}$ & $\begin{array}{l}0.296 \\
(2.17)\end{array}$ \\
\hline Education & (a) & $\begin{array}{l}0.000 \\
(0.15)\end{array}$ & $\begin{array}{l}-0.005 \\
(1.96)\end{array}$ & $\begin{array}{l}-0.017 \\
(2.14)\end{array}$ \\
\hline Age at migration & (a) & $\begin{array}{l}-0.003 \\
(3.60)\end{array}$ & $\begin{array}{l}-0.003 \\
(3.85)\end{array}$ & $\begin{array}{l}-0.004 \\
(1.66)\end{array}$ \\
\hline Female & (a) & $\begin{array}{l}-0.059 \\
(4.49)\end{array}$ & $\begin{array}{l}-0.061 \\
(4.14)\end{array}$ & $\begin{array}{l}-0.144 \\
(3.01)\end{array}$ \\
\hline Proficient in English & (a) & $\begin{array}{l}0.109 \\
(5.81)\end{array}$ & $\begin{array}{l}0.110 \\
(5.46)\end{array}$ & $\begin{array}{l}0.511 \\
(8.67)\end{array}$ \\
\hline $\begin{array}{l}\text { Family Structure } \\
\text { MUS }^{(\mathrm{g})}\end{array}$ & (a) & $\begin{array}{l}0.017 \\
(0.73)\end{array}$ & $\begin{array}{l}0.014 \\
(0.54)\end{array}$ & $\begin{array}{l}0.059 \\
(0.76)\end{array}$ \\
\hline $\mathrm{OS}^{(\mathrm{h})}$ & (a) & $\begin{array}{l}-0.001 \\
(0.08)\end{array}$ & $\begin{array}{l}-0.017 \\
(0.81)\end{array}$ & $\begin{array}{c}0.091 \\
(1.40)\end{array}$ \\
\hline $\operatorname{KIDS}^{(\mathrm{i})}$ & (a) & $\begin{array}{l}-0.002 \\
(0.16)\end{array}$ & $\begin{array}{l}0.005 \\
(0.30)\end{array}$ & $\begin{array}{l}-0.076 \\
(1.50)\end{array}$ \\
\hline $\begin{array}{l}\text { Birthplace (Southern Eur } \\
\text { English-speaking } \\
\text { developed countries }\end{array}$ & (a) & $\begin{array}{l}-0.047 \\
(1.64)\end{array}$ & (a) & (a) \\
\hline Western Europe & (a) & $\begin{array}{l}-0.074 \\
(1.74)\end{array}$ & (a) & (a) \\
\hline Northern Europe & (a) & $\begin{array}{l}0.016 \\
(0.34)\end{array}$ & (a) & (a) \\
\hline
\end{tabular}




\begin{tabular}{|c|c|c|c|c|}
\hline Eastern Europe & (a) & $\begin{array}{l}-0.027 \\
(0.58)\end{array}$ & (a) & (a) \\
\hline $\begin{array}{l}\text { The USSR and the Baltic } \\
\text { States }\end{array}$ & (a) & $\begin{array}{l}-0.151 \\
(3.03)\end{array}$ & (a) & (a) \\
\hline The Middle East & (a) & $\begin{array}{l}-0.034 \\
(1.10)\end{array}$ & (a) & (a) \\
\hline North Africa & (a) & $\begin{array}{l}-0.045 \\
(0.82)\end{array}$ & (a) & (a) \\
\hline South East Asia & (a) & $\begin{array}{l}-0.077 \\
(2.69)\end{array}$ & (a) & (a) \\
\hline North East Asia & (a) & $\begin{array}{l}-0.069 \\
(2.13)\end{array}$ & (a) & (a) \\
\hline Southern Asia & (a) & $\begin{array}{l}-0.063 \\
(1.97)\end{array}$ & (a) & (a) \\
\hline $\begin{array}{l}\text { South and Central } \\
\text { America }\end{array}$ & (a) & $\begin{array}{l}-0.007 \\
(0.15)\end{array}$ & (a) & (a) \\
\hline Remaining countries & (a) & $\begin{array}{l}-0.016 \\
(0.50)\end{array}$ & (a) & (a) \\
\hline Birthplace concentration & (a) & (a) & $\begin{array}{l}-0.007 \\
(5.09)\end{array}$ & $\begin{array}{l}-0.014 \\
(3.65)\end{array}$ \\
\hline Life expectancy at birth & (a) & (a) & $\begin{array}{l}0.002 \\
(1.70)\end{array}$ & $\begin{array}{l}0.007 \\
(1.65)\end{array}$ \\
\hline Distance/1000 & (a) & (a) & $\begin{array}{l}0.002 \\
(0.79)\end{array}$ & $\begin{array}{l}0.008 \\
(1.26)\end{array}$ \\
\hline$\hat{\mu}_{1}$ & (c) & (c) & (c) & $\begin{array}{c}0.769 \\
(18.01)\end{array}$ \\
\hline$\hat{\mu}_{2}$ & (c) & (c) & (c) & $\begin{array}{c}1.555 \\
(51.41)\end{array}$ \\
\hline$\hat{\mu}_{3}$ & (c) & (c) & (c) & $\begin{array}{c}2.904 \\
(87.80)\end{array}$ \\
\hline$R^{2}$ & 0.012 & 0.054 & 0.065 & $0.034^{(\mathrm{d})}$ \\
\hline$F / \chi^{2}$ & $10.38^{(\mathrm{e})}$ & $8.28^{(\mathrm{e})}$ & $13.20^{(\mathrm{e})}$ & 203.56 \\
\hline Prediction success rate (\%) & (c) & (c) & (c) & 48.20 \\
\hline Sample size & 3349 & 3349 & $2690^{(\mathrm{f})}$ & $2693^{(\mathrm{f})}$ \\
\hline
\end{tabular}

Note: ' $\mathrm{t}$ ' statistics in parentheses.

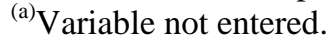


${ }^{(b)}$ ENS denotes Employer Nomination Scheme.

(c) Not relevant.

${ }^{(d)}$ The Pseudo $R^{2}$ is calculated as $1-\left(\mathrm{L}_{\mathrm{m}} / \mathrm{L}_{0}\right)$, where $\mathrm{L}_{\mathrm{m}}=$ the log-likelihood value of the model and $\mathrm{L}_{0}$ $=$ the log-likelihood value if the non-intercept coefficients are restricted to zero (see Veall and Zimmermann, 1996).

${ }^{(\mathrm{e})}$ Figures listed for the OLS models are F statistics.

${ }^{(f)}$ Sample size reduces by 656 due to rejection of immigrants with zero birthplace concentration (634), and missing value for the life expectancy at birth measure (24), with both missing for two observations.

${ }^{(\mathrm{g})}$ Whether a spouse who was part of the migrating unit is present in the household.

(h) Whether a spouse who was not part of the migrating unit is present in the household.

${ }^{(i)}$ Whether children in the household.

Source: Longitudinal Survey of Immigrants to Australia (Wave Three). 
Table 8: Self-Assessed Good Health Over 4 Weeks Prior to Interviews of Immigrants 15-64 Years of Age at Immigration, Longitudinal Survey of Immigrants to Australia, Waves One and Three

\begin{tabular}{|c|c|c|c|c|}
\hline & \multicolumn{2}{|c|}{ Independent Probit } & \multicolumn{2}{|c|}{ Bivariate Probit } \\
\hline Variable & Wave 1 & Wave 3 & Wave 1 & Wave 3 \\
\hline Constant & $\begin{array}{l}2.404 \\
(8.28)\end{array}$ & $\begin{array}{l}1.515 \\
(6.80)\end{array}$ & $\begin{array}{l}2.399 \\
(7.61)\end{array}$ & $\begin{array}{l}1.533 \\
(6.91)\end{array}$ \\
\hline $\begin{array}{l}\text { Visa Category (Indepen } \\
\text { Humanitarian }\end{array}$ & $\begin{array}{l}-0.346 \\
(2.26)\end{array}$ & $\begin{array}{l}-0.315 \\
(2.75)\end{array}$ & $\begin{array}{l}-0.347 \\
(2.03)\end{array}$ & $\begin{array}{l}-0.326 \\
(2.82)\end{array}$ \\
\hline Preferential Family & $\begin{array}{l}-0.066 \\
(0.44)\end{array}$ & $\begin{array}{l}-0.036 \\
(0.35)\end{array}$ & $\begin{array}{l}-0.105 \\
(0.64)\end{array}$ & $\begin{array}{l}-0.051 \\
(0.49)\end{array}$ \\
\hline Concessional Family & $\begin{array}{l}0.154 \\
(0.88)\end{array}$ & $\begin{array}{l}0.049 \\
(0.39)\end{array}$ & $\begin{array}{l}0.141 \\
(0.80)\end{array}$ & $\begin{array}{l}0.043 \\
(0.35)\end{array}$ \\
\hline Business Skills/ENS ${ }^{(a)}$ & $\begin{array}{l}0.041 \\
(0.18)\end{array}$ & $\begin{array}{l}0.335 \\
(1.64)\end{array}$ & $\begin{array}{l}0.026 \\
(0.11)\end{array}$ & $\begin{array}{l}0.318 \\
(1.56)\end{array}$ \\
\hline Education & $\begin{array}{l}0.007 \\
(0.63)\end{array}$ & $\begin{array}{l}0.000 \\
(0.04)\end{array}$ & $\begin{array}{l}0.006 \\
(0.52)\end{array}$ & $\begin{array}{l}0.001 \\
(0.11)\end{array}$ \\
\hline Age at migration & $\begin{array}{l}-0.013 \\
(3.27)\end{array}$ & $\begin{array}{l}-0.011 \\
(3.48)\end{array}$ & $\begin{array}{l}-0.013 \\
(2.80)\end{array}$ & $\begin{array}{l}-0.011 \\
(3.32)\end{array}$ \\
\hline Female & $\begin{array}{l}-0.292 \\
(3.79)\end{array}$ & $\begin{array}{l}-0.271 \\
(4.38)\end{array}$ & $\begin{array}{l}-0.285 \\
(3.51)\end{array}$ & $\begin{array}{l}-0.272 \\
(4.22)\end{array}$ \\
\hline Proficient in English & $\begin{array}{l}0.372 \\
(4.04)\end{array}$ & $\begin{array}{l}0.414 \\
(5.74)\end{array}$ & $\begin{array}{l}0.358 \\
(3.87)\end{array}$ & $\begin{array}{l}0.376 \\
(4.94)\end{array}$ \\
\hline $\begin{array}{l}\text { Family Structure } \\
\text { MUS }^{\left({ }^{b}\right)}\end{array}$ & $\begin{array}{l}-0.130 \\
(1.11)\end{array}$ & $\begin{array}{l}0.062 \\
(0.63)\end{array}$ & $\begin{array}{l}-0.103 \\
(0.87)\end{array}$ & $\begin{array}{l}0.071 \\
(0.73)\end{array}$ \\
\hline $\mathrm{OS}^{(\mathrm{c})}$ & $\begin{array}{l}-0.059 \\
(0.48)\end{array}$ & $\begin{array}{l}-0.006 \\
(0.07)\end{array}$ & $\begin{array}{l}-0.024 \\
(0.18)\end{array}$ & $\begin{array}{l}0.004 \\
(0.05)\end{array}$ \\
\hline $\operatorname{KIDS}^{(\mathrm{d})}$ & $\begin{array}{l}0.138 \\
(1.60)\end{array}$ & $\begin{array}{l}-0.015 \\
(0.24)\end{array}$ & $\begin{array}{l}0.127 \\
(1.38)\end{array}$ & $\begin{array}{r}-0.019 \\
(0.31)\end{array}$ \\
\hline $\begin{array}{l}\text { Birthplace (Southern Eu } \\
\text { English-speaking } \\
\text { developed countries }\end{array}$ & $\begin{array}{l}-0.623 \\
(3.32)\end{array}$ & $\begin{array}{l}-0.182 \\
(1.35)\end{array}$ & $\begin{array}{l}-0.608 \\
(3.32)\end{array}$ & $\begin{array}{l}-0.162 \\
(1.27)\end{array}$ \\
\hline Western Europe & $\begin{array}{c}-0.606 \\
(2.25)\end{array}$ & $\begin{array}{c}-0.301 \\
(1.50)\end{array}$ & $\begin{array}{c}-0.572 \\
(2.20)\end{array}$ & $\begin{array}{l}-0.277 \\
(1.37)\end{array}$ \\
\hline Northern Europe & $\begin{array}{c}-0.971 \\
(2.59)\end{array}$ & $\begin{array}{l}0.300 \\
(0.67)\end{array}$ & $\begin{array}{l}-0.950 \\
(2.56)\end{array}$ & $\begin{array}{l}0.301 \\
(0.70)\end{array}$ \\
\hline
\end{tabular}




\begin{tabular}{|c|c|c|c|c|}
\hline Eastern Europe & $\begin{array}{l}-0.323 \\
(1.09)\end{array}$ & $\begin{array}{l}-0.086 \\
(0.38)\end{array}$ & $\begin{array}{l}-0.297 \\
(0.97)\end{array}$ & $\begin{array}{l}-0.068 \\
(0.31)\end{array}$ \\
\hline $\begin{array}{l}\text { The USSR and the } \\
\text { Baltic States }\end{array}$ & $\begin{array}{l}-0.780 \\
(3.37)\end{array}$ & $\begin{array}{l}-0.526 \\
(2.83)\end{array}$ & $\begin{array}{l}-0.744 \\
(2.83)\end{array}$ & $\begin{array}{l}-0.512 \\
(2.64)\end{array}$ \\
\hline The Middle East & $\begin{array}{l}-0.372 \\
(1.97)\end{array}$ & $\begin{array}{l}-0.155 \\
(1.11)\end{array}$ & $\begin{array}{l}-0.371 \\
(1.99)\end{array}$ & $\begin{array}{l}-0.141 \\
(1.04)\end{array}$ \\
\hline North Africa & $\begin{array}{l}-0.423 \\
(1.25)\end{array}$ & $\begin{array}{l}-0.169 \\
(0.66)\end{array}$ & $\begin{array}{l}-0.375 \\
(1.08)\end{array}$ & $\begin{array}{l}-0.152 \\
(0.59)\end{array}$ \\
\hline South East Asia & $\begin{array}{l}-0.729 \\
(4.38)\end{array}$ & $\begin{array}{l}-0.299 \\
(2.46)\end{array}$ & $\begin{array}{l}-0.692 \\
(4.11)\end{array}$ & $\begin{array}{l}-0.286 \\
(2.43)\end{array}$ \\
\hline North East Asia & $\begin{array}{l}-0.731 \\
(3.99)\end{array}$ & $\begin{array}{l}-0.296 \\
(2.16)\end{array}$ & $\begin{array}{l}-0.708 \\
(3.90)\end{array}$ & $\begin{array}{l}-0.282 \\
(2.16)\end{array}$ \\
\hline Southern Asia & $\begin{array}{l}-0.341 \\
(1.62)\end{array}$ & $\begin{array}{l}-0.255 \\
(1.76)\end{array}$ & $\begin{array}{l}-0.320 \\
(1.52)\end{array}$ & $\begin{array}{l}-0.237 \\
(1.69)\end{array}$ \\
\hline $\begin{array}{l}\text { South and Central } \\
\text { America }\end{array}$ & $\begin{array}{l}-0.218 \\
(0.62)\end{array}$ & $\begin{array}{l}0.010 \\
(0.04)\end{array}$ & $\begin{array}{l}-0.227 \\
(0.67)\end{array}$ & $\begin{array}{l}0.019 \\
(0.08)\end{array}$ \\
\hline Remaining countries & $\begin{array}{l}-0.532 \\
(2.38)\end{array}$ & $\begin{array}{l}-0.001 \\
(0.01)\end{array}$ & $\begin{array}{l}-0.506 \\
(2.33)\end{array}$ & $\begin{array}{l}0.026 \\
(0.16)\end{array}$ \\
\hline$\chi^{2}$ & 132.45 & 168.25 & \multicolumn{2}{|c|}{246.48} \\
\hline Prediction success rate (\%) & 93.73 & 87.48 & \multicolumn{2}{|c|}{85.54} \\
\hline Correlation coefficient $\rho$ & (e) & (e) & \multicolumn{2}{|c|}{$\begin{array}{l}0.392 \\
(8.53)\end{array}$} \\
\hline Sample size & 3,347 & 3,347 & \multicolumn{2}{|c|}{3,347} \\
\hline
\end{tabular}

${ }^{(a)}$ ENS denotes Employer Nomination Scheme.

${ }^{(b)}$ Whether a spouse who was part of the migrating unit is present in the household.

${ }^{(c)}$ Whether a spouse who was not part of the migrating unit is present in the household.

${ }^{(d)}$ Whether children in the household.

${ }^{\left({ }^{(}\right)}$Not relevant

Source: Longitudinal Survey of Immigrants to Australia (Waves One and Three). 
TABLE 9: Predicted Percentages Reporting Good Health from Table 8

\begin{tabular}{|c|c|c|c|c|}
\hline Variable & $\begin{array}{l}\text { Wave } 1^{\text {(a) }} \\
\text { (i) }\end{array}$ & $\begin{array}{c}\text { Wave } 3^{(a)} \\
\text { (ii) }\end{array}$ & $\begin{array}{c}\text { Wave } 1 * \text { Wave } 3 \text {, } \\
\text { Single Equation } \\
\text { Probit Models }{ }^{(\mathrm{b})} \\
\text { (iii) }\end{array}$ & $\begin{array}{c}\text { Wave 1* Wave 3, } \\
\text { Bivariate Probit } \\
\text { Model }^{\left({ }^{2}\right)} \\
\text { (iv) }\end{array}$ \\
\hline \multicolumn{4}{|l|}{ Mean Values of } & 83.20 \\
\hline \multicolumn{5}{|l|}{ Age } \\
\hline 20 & 95.41 & 89.87 & 85.74 & 86.77 \\
\hline 30 & 94.05 & 87.77 & 82.55 & 83.86 \\
\hline 40 & 92.39 & 85.39 & 78.89 & 80.53 \\
\hline 50 & 90.40 & 82.72 & 74.78 & 76.80 \\
\hline 60 & 88.06 & 79.75 & 70.22 & 72.67 \\
\hline \multicolumn{5}{|c|}{ English Proficiency } \\
\hline Proficient & 95.29 & 89.26 & 85.05 & 85.89 \\
\hline Not Proficient & 90.34 & 79.59 & 71.90 & 74.98 \\
\hline \multicolumn{5}{|l|}{ Gender } \\
\hline Male & 95.28 & 89.80 & 85.57 & 86.54 \\
\hline Female & 91.62 & 84.11 & 77.06 & 78.97 \\
\hline \multicolumn{5}{|l|}{ Birthplace } \\
\hline \multicolumn{5}{|l|}{ USSR and the } \\
\hline Baltic States & 78.03 & 73.52 & 57.37 & 62.54 \\
\hline South East Asia & 83.46 & 81.87 & 68.33 & 72.07 \\
\hline North East Asia & 81.44 & 81.12 & 66.06 & 69.99 \\
\hline \multicolumn{5}{|c|}{ Combinations of Variables } \\
\hline \multicolumn{5}{|c|}{ Females from } \\
\hline \multicolumn{5}{|l|}{ USSR and the } \\
\hline Baltic States & 73.26 & 68.69 & 50.32 & 56.31 \\
\hline
\end{tabular}

Note: The predicted probabilities were multiplied by 100.0 to obtain percentages.

(a) calculated as $\Phi(x \beta)$ from the single-equation probit estimates in Table 8.

(b) calculated as the product of the predictions in columns (i) and (ii) under the assumption of independence.

${ }^{\text {(c) }}$ calculated as $F\left(\beta^{\text {Wave1 }} X_{i}^{\text {Wave1 }}, \beta^{\text {Wave3 }} X_{i}^{\text {Wave3 }}\right.$,0.3922 $)$ from the bivariate probit estimates in Table 8, where $\mathrm{F}$ is the bivariate standard normal cumulative density function. 


\section{APPENDIX A}

The questions on Health in the wave 1 interview are as follows:

Q1. Please tell me (the interviewer) if you have any of the long-term conditions mentioned that restrict you in any physical activities or doing work?

By long-term, I mean any condition that has lasted, or is likely to last, six months

\section{(ACCEPT MULTIPLES)}

- Arthritis or rheumatism

- Hearing problem or deafness

- Blindness or impaired vision

- Nerves or stress problems

- Heart disorder

- Loss of limb or any other part of the body

- Diabetes

- Asthma

- Any permanent loss of memory or loss of mental ability

- Any other long-term condition that restricts you in physical activities or doing work (SPECIFY)

- None of the above ..$(\rightarrow \mathrm{Q} 3)$

Q2. Did you have this condition before you immigrated to Australia?

- Yes

- No

Q3. Over the last month, would you say your health has generally been...

- Very good

- Good

- Fair

- Poor

- Very poor 
The questions on Health in the wave 3 interview are as follows:

Q1. Please tell me (the interviewer) if you have any of the long-term conditions mentioned that restrict you in any physical activities or doing work?

By long-term, I mean any condition that has lasted, or is likely to last, six months

\section{(ACCEPT MULTIPLES)}

- Arthritis or rheumatism

- Hearing problem or deafness

- Blindness or impaired vision

- Nerves or stress problems

- Heart disorder

- Loss of limb or any other part of the body

- Diabetes

- Hepatitis or other liver disorder

- Asthma

- Tuberculosis

- Any permanent loss of memory or loss of mental ability

- Kidney disorder

- Any other long-term condition that restricts you in physical activities or doing work (SPECIFY)

- None of the above

Q2. Over the last four weeks, in general has your health been...

- Very good

- Good

- Fair

- Poor

- Very poor 